\title{
Natural Plant Resources for Sustainable Development: Insights from Community Use in the Chimanimani Trans-Frontier Conservation Area, Mozambique
}

\author{
Alex Hudson ${ }^{1}$ (D) - William Milliken ${ }^{1} \cdot J_{0}$ anathan Timberlake ${ }^{2} \cdot$ Peter Giovannini $^{1} \cdot$ Valdemar Fijamo $^{3} \cdot$ Joao Massunde $^{4}$. \\ Hercilia Chipanga $^{4} \cdot$ Milagre Nivunga $^{4} \cdot$ Tiziana Ulian $^{1}$
}

Published online: 20 February 2020

(C) The Author(s) 2020

\begin{abstract}
In rural African communities, wild plant species are a valuable resource that are often threatened by agricultural conversion and overexploitation. To understand the harvest and sale of wild plant species that provide fruits and raw materials for artisanal products, this study used ethnobotanical and socio-economic methods to engage communities in the Chimanimani Trans-Frontier Conservation Area, Mozambique. Use was dependent on local availability and market accessibility. Incomes are made from Uapaca kirkiana fruits in some communities and Strychnos madagascariensis in others; some earn money from Cyperus spp. mats whilst others use Phragmites mauritianus. Less marketed items included baskets made from numerous species (including Oxytenanthera abyssinica) and wooden implements (e.g. made from Pterocarpus angolensis) which are used to process, store and transport maize. Conservation and development could potentially benefit from value-addition activities, new management systems (like agroforestry), or population protection and restoration. This should include analysis of population extents and production levels.
\end{abstract}

Keywords Policy $\cdot$ Non-timber forest products $\cdot$ Socioeconomics $\cdot$ Ethnobotany $\cdot$ Sustainable development $\cdot$ Community use Livelihood development $\cdot$ Chimanimani Trans-frontier conservation area $\cdot$ Mozambique

\section{Introduction}

Indigenous wild species support the livelihoods of poor rural communities throughout the world (Angelsen et al. 2014; Dzerefos et al. 2016; Towns and van Andel 2016). However, their availability is decreasing as government development strategies fail to support conservation or sustainable use while they continue to promote intensively managed crops such as like maize (Caro et al. 2005; Dias 2013) thus driving deforestation (Phelps et al. 2013).

Both international efforts, such as the Convention on Biological Diversity (Aichi Targets 2, 4 and 18) and the Sustainable Development Goals (12 and 15) (CBD 2010; UN General Assembly 2015), and national policies, such as

\footnotetext{
Alex Hudson

alexhudson21@gmail.com

William Milliken

w.milliken@kew.org

Peter Giovannini

peter.giovannini@gmail.com

Valdemar Fijamo

valdfijamo@gmail.com

Joao Massunde

joaomassunde@gmail.com

Hercilia Chipanga

hercilia.chipanga@gmail.com
}

\author{
Milagre Nivunga \\ milagremicaia@gmail.com \\ Tiziana Ulian \\ t.ulian@kew.org
}

1 Department of Natural Capital and Plant Health, Royal Botanic Gardens, Kew, Wakehurst Place, West Sussex, RH17 6TN UK

230 Warren lane, East Dean, Sussex, BN20 0EW UK

3 Agricultural Research Institute of Mozambique (Instituto de Investigação Agrária de Moçambique), 3658 Maputo, CP, Mozambique

4 Micaia Foundation, PO Box 121, Chimoio, Mozambique 
Mozambique's National Strategy and action plan of biological diversity of Mozambique (MLERD 2015), ${ }^{1}$ seek to address widespread loss of biodiversity and increase the sustainable use of resources.

Enhancing the value of natural areas is an alternative to counter current intensification strategies by increasing the value of local wild plant resources with markets that are more stable than crops since they not linked to international prices (Angelsen 2010; Dias 2013; Sunderlin et al. 2005). However, market expansion can also lead to unsustainable overexploitation of the resources if their availability is also not considered in development strategies (van Andel et al. 2015; Pei et al. 2009;)

Development may also be unsuccessful if local communities are not consulted during planning and implementation (Dzerefos et al. 2016; Laird et al. 2010; Pei et al. 2009; Schafer and Bell 2002). A number of factors need to be considered in the development of successful policies, including: variability in communities' knowledge, since poor engagement can lead to the inadequate provision of training or technology; market availability; existing policies and institutions; and equitable access to benefits to avoid their being captured by 'elite' stakeholders (Dove 1993; Sunderlin et al. 2005).

Across Africa, many poor communities are reliant on wild plants for nutrition, medicine, and other household and cultural uses, and they may be valued over cultivated crops (Towns et al. 2013). These uses need to be understood in the local context so that they can then be incorporated into sustainable development strategies that help to halt biodiversity loss (Gebramlak et al. 2016; Rankoana 2016).

\section{Background}

Our research goal was to generate data to inform conservation and development policies and research in the Chimanimani Trans-Frontier Conservation Area (TFCA) in Western Mozambique. The Chimanimani TFCA's natural areas are under pressure from increasing itinerant agriculture and illegal logging (Ghiurghi et al. 2010; Virtanen 2005), while at the same time important crops are under threat from pests and diseases, making the development of sustainable alternative agricultural practices a priority (Abrahams et al. 2017).

We identified the most harvested and marketed wild plant species that provide communities with the raw materials for artisanal products (e.g., mats, baskets, and household wooden objects) and edible fruits so that this data can be used to target research and formulate policies that improve the chances of successful sustainable development of these species, rather

\footnotetext{
${ }^{1}$ Targets $4,11 \mathrm{~b}$, and 18 address ecological sustainable systems, effectively and equitably managed protected areas, and emphasize value and respect of traditional knowledge and uses of biodiversity.
}

than policies that limit local resource use and promote further expansion of cash crops.

We did not consider other important subsistence uses, such as firewood and charcoal, due to time constraints and already available research on the importance of known viable populations of fruit and artisanal species across southern Africa (Timberlake et al. 2016b). A local development NGO in the study area, the MICAIA Foundation, also has experience with Non-Timber Forest Products (NTFP), including products and value chains using fruits from Adansonia digitata, which could be beneficial to the development of products and markets.

\section{Methods}

We conducted an ethnobotanical survey with a mixed positivist approach to record information about local indigenous plant use by communities (Ghimire et al. 2005). We collected data at focus groups designed to gather a broad range of information from Chimanimani TFCA communities who have different access to natural resources. Concurrently, we collected socioeconomic data to provide additional information about species' suitability for use in sustainable development plans (Angelsen et al. 2014; Bakkegaard et al. 2016).

\section{Study Area}

The study was conducted in June 2017 within three 'regulados' (chieftainships) of the Chimanimani National Reserve $\left(634 \mathrm{Km}^{2}\right)$ buffer zone $\left(1723 \mathrm{Km}^{2}\right)$, in the Manica province of Mozambique $\left(16^{\circ} 23^{\prime} 7.08^{\prime \prime} \mathrm{S}\right.$ to $21^{\circ} 35^{\prime} 9.6^{\prime \prime} \mathrm{S}$ latitude; $32^{\circ} 22^{\prime} 0.12^{\prime \prime} \mathrm{E}$ to $34^{\circ} 32^{\prime} 5.64^{\prime \prime} \mathrm{E}$ longitude), which comprise the Mozambican side of the Chimanimani TFCA, with largely nutrient poor Schist and quartzite soils (Fig. 1, Table 1) (Ghiurghi et al. 2010; Wursten et al. 2017). includes the Chimanimani Mountain range with Mount Binga, the highest point in Mozambique at $2436 \mathrm{~m}$ (Timberlake et al. 2016a).

The Chimanimani TFCA was established by the South African Development Community (SADC) (SADC 1999) and includes both a core zone and buffer zone. The buffer zone is an area in which communities are legally allowed to sustainably use resources while the resources of the remaining tropical lowland rain forest and core zone are conserved (Ghiurghi et al. 2010; SADC 2002; SADC Secretariat 2013).

Buffer zone communities reside in nine to twelve regulados, each a traditional but dynamic group of communities and villages with the same chief (Ghiurghi et al. 2010). The exact number is uncertain because of complex migration and governing histories that have led to varied claims for land (Schafer and Bell 2002; Virtanen 2005; Walker 2012), particularly along the border with Zimbabwe, leading to disputes 
Fig. 1 The Chimanimani TransFrontier Conservation Area in Manica province, Mozambique. Sites of focus group meetings are shown

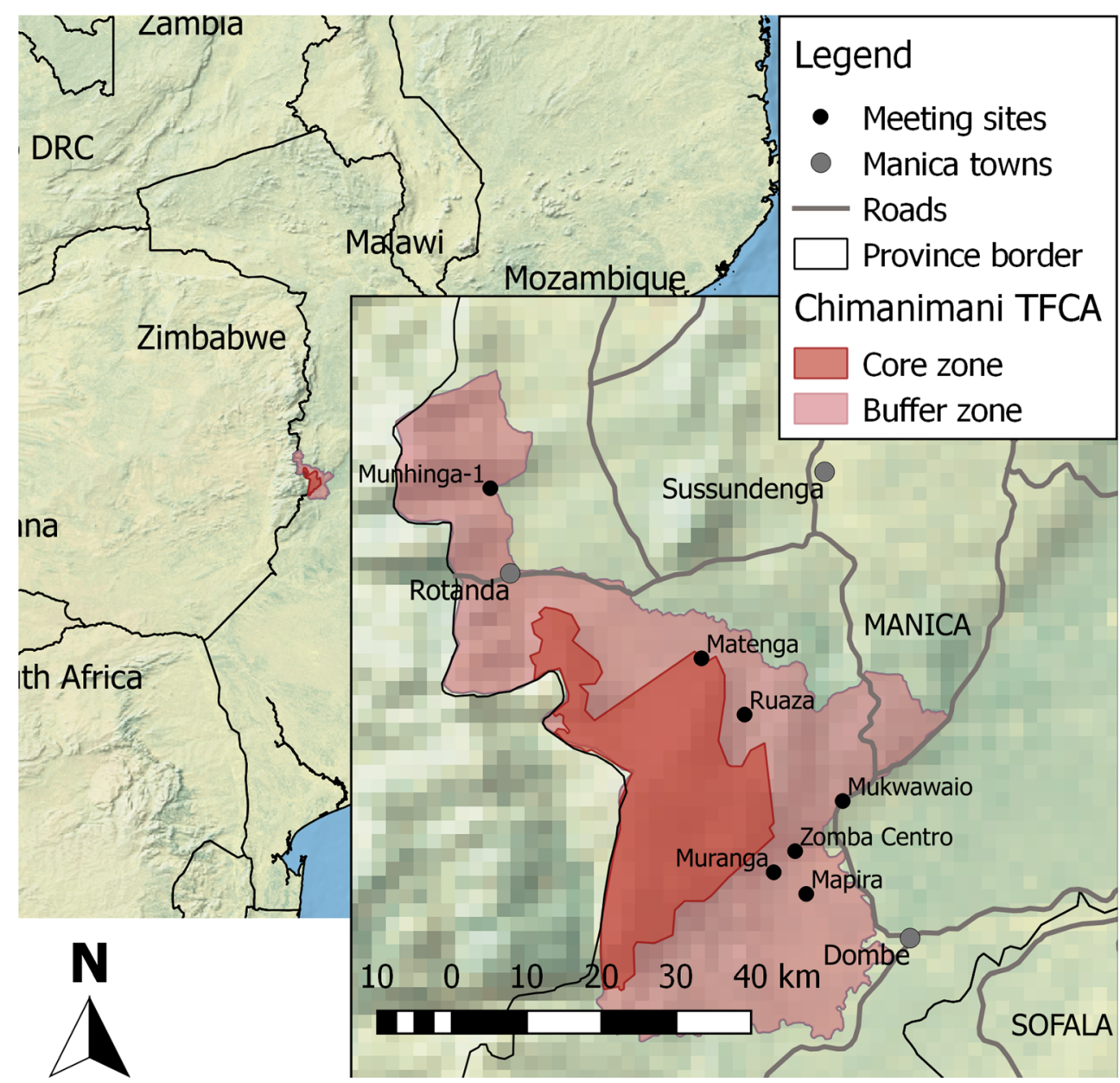

among groups that traditionally resided across the two countries' border or that migrated during political upheavals.

Communities are situated on the foot-slopes, pediplains, and highlands, where they practice mainly subsistence agriculture. The local language is Ndau, a dialect of Shona (Timberlake et al. 2016a; Virtanen 2005). All areas are situated between $150 \mathrm{~m}$ and $1200 \mathrm{~m}$ elevation, receiving between 1100 to $1400 \mathrm{~mm}$ of rainfall per year (Ghiurghi et al. 2010).

\section{Sampling and Study Participants}

Focus groups were conducted with two local bilingual translators (Portuguese - Shona). One translator was from the NGO Micaia Foundation and had worked extensively with the communities. The second was a member of the community - a schoolteacher or community member who was multilingual from past work. All were male.

The format of the focus groups, language, and questions were tested during a pilot in Mpunga regulado (Mukwawaio). One outcome of this was that questions related to land tenure and management rules were removed because they did not lead to any elaboration (some management taboos were gained from key informant interviews).
Our study focussed on villages from Mahate, Zomba, and Mussimua regulados (Table 1). The first two are found to the east of the Chimanimani mountain range with Mussimua to the north. Regulado selection was stratified to include those with known large viable populations of regional economic species for artisanal products (Cyperus papyrus L.) and foods (Uapaca kirkiana Müll.Arg.) (Kadzere et al. 2007; Mithöfer and Waibel 2003; Terer et al. 2012; Timberlake et al. 2016b; van Dam et al. 2014).

Villages were sampled opportunistically from these using the knowledge of partners and their local networks. Three villages were selected in the Zomba (Muranga, Mapira, and Zomba Centro), two in Mahate (Matenga and Ruaza) and one in Mussimua (Munhinga-1). Zomba and Mussimua, being closer to the roads, have more villages and higher populations, so we decided to hold meetings with more villages in these regulados.

Leading up to the focus groups villages were informed of the meetings and that their participation was voluntarily, although food was provided to attendees, which could have provided an incentive for the poorer sectors of the communities. To ensure women felt comfortable to contribute to 
discussions, separate, concurrent meetings were held for men and for women.

In total, we held 12 focus group meetings. Prior Informed Consent was gained from participants after explaining the research and the expected use of data using a prepared statement. The International Society of Ethnobiology (ISE) Code of Ethics was followed. Focus groups had between two and 44 participants and lasted between 75 and $185 \mathrm{~min}$.

Attendance varied according to the size of the villages and the distance to main roads, making advertising of meetings harder. Discussions with larger groups were louder and more energetic. We expected our methods to encourage participation by all attendees, with free listing continued until no participants could add to the lists to allow everybody to independently contribute species they regarded as most harvested or sold. We undertook key informant interviews with artisans, a fruit collector, and the Mussimua regulo (chief) opportunistically.

\section{Data Collection and Analysis}

In focus group meetings, attendees were led through a free listing exercise to create two lists of local names, recorded in Ndau, of a) wild edible fruit species, and b) wild species that provide raw materials for artisanal products. Plant names were added to the lists until community members could not mention any new ones.

The most harvested and the most sold species were determined using an open voting system, which we chose for speed of completion and because the subject was not considered to require a secret ballot.

For each of the lists, attendees were asked to vote for the species they (1) harvest most, and (2) sell most products of. Marbles were used to allow only a single vote for each round. After explaining the system, the full list was read to the group with time allowed for decision-making. Then each species was called in turn with time given to vote. If a result was unanimous then a second vote was completed to determine the second most important species.

During the first meetings in Muranga, attendees were asked to vote for the species they would least like to lose. To reduce the total length of the meetings, this was discontinued in subsequent meetings and the data excluded from the final analysis.

Standardised semi-structured questions were then asked to encourage further discussions on the socioeconomics of the top two or three species from each list. These were adapted from Bakkegaard et al. (2016) and the Toolkit for Ecosystem Service Site-based Assessment (TESSA - Harvested wild goods method 1) (Peh et al. 2013). This included creation of activity calendars (harvest, consumption, and sale) and collection of socioeconomic information regarding the harvest and sale of products (i.e., associated expenditures, prices of 
products, harvest areas). Responses to questions were categorised following Bakkegaard et al. (2016), recording any extra information mentioned.

After the focus groups, the research team accompanied village guides to find and collect specimens of species that received the most votes. During collection, we asked our guides further questions about the uses of collected species. Women were included as guides in Muranga, but they were reluctant to join a group of men alone in the field, thus only male guides were sought in the other villages.

Between two and 18 species were collected per village. Specimens were collected, dried and pressed in the field, and then taken to be identified and stored in herbariums at the Royal Botanic Gardens, Kew (RBG Kew) and the Instituto de Investigação Agrária de Moçambique (IIAM). Family names use the APG III system (Angiosperm Phylogeny Group 2009), with nomenclature and species authorities following The International Plant Names Index (2017) database.

Permissions to collect and export specimens were granted before the fieldwork. This included authorisation from the Administração Nacional das Áreas de Conservação organised through MICAIA Foundation and IIAM. To triangulate the information collected in focus groups, six interviews of key informants were undertaken by convenience sampling: mat producers from Muranga (Zomba) and Zomba centro; a basket and peneira producer from Zomba centro; a pounding basin producer from Ruaza (Mahate); a Muzanje harvester in Munhinga-1 (Mussimua); and the Mussimua regulo. We used semi-structured interviews to collect information about target products to find out how species are used, harvest and production methods, and the prices of products and associated expenditures of harvesting and processing.

We used Microsoft Excel to store the data and R 3.3.3 for analysis. For prices of items, we calculated minimum and maximum values using data from community groups and key informant interviews. We followed standards for improving and reporting ethnobotany research (Albuquerque and Hanazaki 2009; Weckerle et al. 2018).

\section{A Note on Vernacular Plant Names}

The Shona population is spread across English (Zimbabwe) and Portuguese (Mozambique) speaking countries. We noticed different spellings of names could be given, varying according to the language standards when applied phonetically, e.g., Mabungwa in English and Mabungua in Portuguese. Additionally, in the case of fruit, the name for the tree or the fruits could be given interchangeably (e.g., the fruits of Mucuvu tree are called Hubvu). For the important species we report the plant name.

All wild plants have associated expenditures for harvesting and production processes, including the purchase of tools, such as axes, hammers, machetes, and saws, as well as transportation, such as bicycles. We calculated annual expenditures from community reported values and the frequency the expenditures are incurred. We calculated lower and upper yearly expenditures because informants often provided ranges for expenditures and number of years as follows:

Item's lower yearly expenditure

$$
=\frac{\text { Lower price of item }}{\text { Max.no.years to replacement }}
$$

Item's upper yearly expenditure

$$
=\frac{\text { Upper price of item }}{\text { Min.no.years to replacement }}
$$

To calculate a maximum value for associated expenditures for a species we compiled a full list of items from the information provided by all communities and by key informants. We added items' lower and upper yearly expenditures together to produce lower and upper expenditure limits for the harvest and production of goods. To tie the mats and baskets together, string could be bought from markets or local species could be used; for these, we added the string expenditures only to the item's upper yearly expenditure.

In Mahate - Ruaza, informants mentioned community sacks for use in collection of raw materials with a single use. Since harvesting is not daily, we used a minimum replacement period of once a month and a maximum of once a year to calculate the lower and upper expenditures of their purchase. All local prices in meticais (Mt) are converted to US\$ equivalent using the latest (2016) Purchasing Power Parity (PPP) conversion factor, private consumption, from the World Bank $-19.413 \mathrm{Mt}=$ US\$1 (The World Bank 2018).

\section{Results}

Over all communities, participants provided a total of 118 vernacular names (62 artisanal and 58 fruits). Across all communities, 14 artisanal (one unidentified) and 14 fruit (one unidentified) species were voted as the most important (Tables 2 and 4).

\section{Artisanal Products}

Some crafted artisanal products are important to the maize industry, such as baskets, peneiras, and pounding implements. Baskets are deep containers used to carry things like farming produce. Peneiras are flat basket-like containers used to sieve maize corn from the husks after pounding. They are made of the same or similar materials, produced using similar methods, and require multiple species: Trichilia emetica, Elachyptera parvifolia or other for the rim/support; Oxytenanthera 


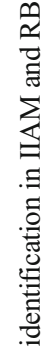

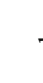
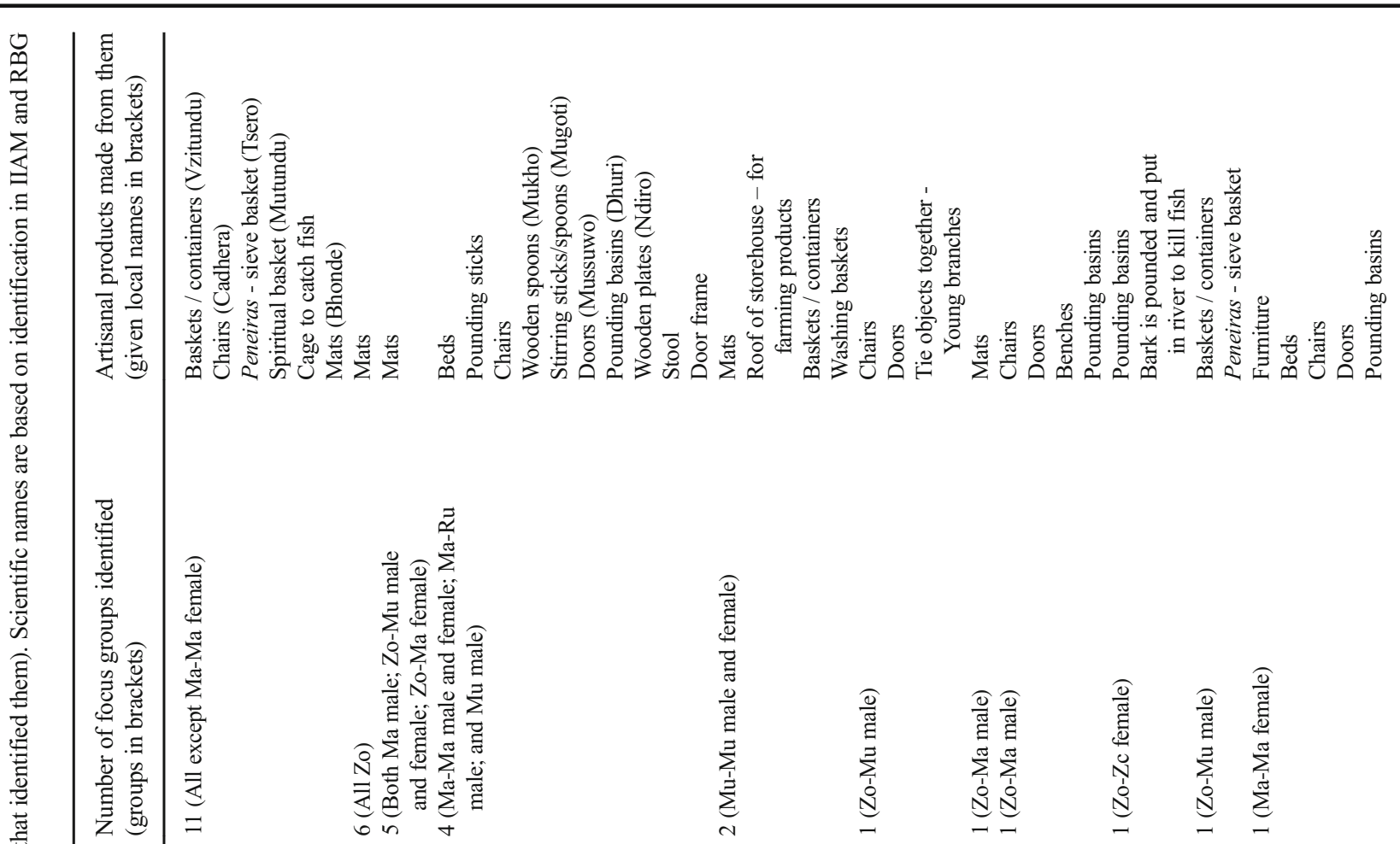

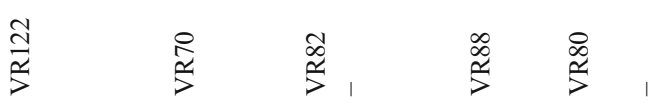
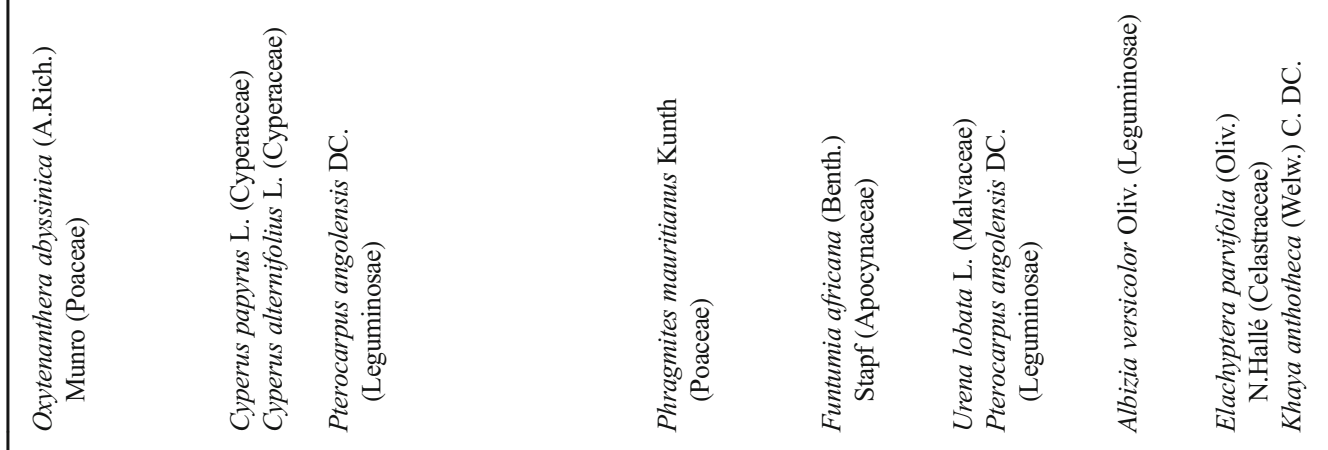

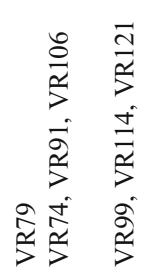

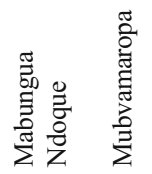

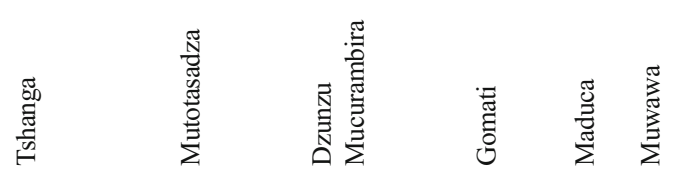


abyssinica for the woven sections; and Smilax anceps to tie everything together.

Several species are used for wooden products; however, only Pterocarpus angolensis voted for by groups in all regulados. The pounding implements are used to crush the maize to remove the husk before it is sieved and ground into mealy powder. A producer from Mahate mentioned that they are only traded locally, when people order them, using naturally fallen tree trunks. In Zomba and Mussimua, it is not possible to wait for trees to fall naturally like this.

Mats are an important trade product. They are made from numerous species: Cyperus papyrus and C. alternifolia in Zomba and Mahate, and Phragmites mauritianus in Mussimua. They are multi-use for sitting, sleeping, burial with the dead, and for drying maize or other produce in the sun.

There are various associated expenditures for harvest and production of each artisanal product (Table 3). To profit from the main artisanal products, one pounding basins and 327 mats (if using bought string instead of natural materials to tie) would need to be sold each year, i.e., Associated expenditure/Mean price.

\section{Fruits}

Two reported fruit species had monetary value and sell quickly when available: Strychnos madagascariensis in Zomba (and Mpunga pilot), and Uapaca kirkiana in Mussimua (Table 4). U. kirkiana fruits are collected from the ground and to be eaten or traded. Key informants mentioned traditional rules in Mussimua that prevent fruits being picked directly from the tree: "monkeys and baboons will raid your other crops," or "when you come back down a lion will be waiting for you." S. madagascariensis fruits are cracked open and the pulp processed into an edible powder, sometimes with the addition of sugar.

Populations of Uapaca kirkiana trees are much larger and more readily available in Mussimua - Munhinga-1, with roads allowing easy access for others to travel there to purchase fruits (Table 4). The community stated a bunch of $U$. kirkiana fruit (c. four) sell for between 5 to $10 \mathrm{Mt}$ (US\$0.26 to US\$0.52). To be profitable, between 35 and 330 bunches would need to be sold per year (between 140 and 1320 fruits).

According to one informant, the incentive was created to travel by bus to towns to sell the Uapaca kirkiana fruits during a particularly bad production year elsewhere (2014), when a c. $20 \mathrm{~kg}$ container of fruits was sold for 200Mt (US\$10.30), with other produce sold simultaneously on the trip. Bus fares were $130 \mathrm{Mt}$ (US\$6.70) for the person and 20Mt (US\$1.03) for the fruits. This would require between 60 and $200 \mathrm{~kg}$ to be sold and a full day of travel ( $1 \mathrm{am}$ to $8 \mathrm{pm}$ ) to cover associated expenditures. 


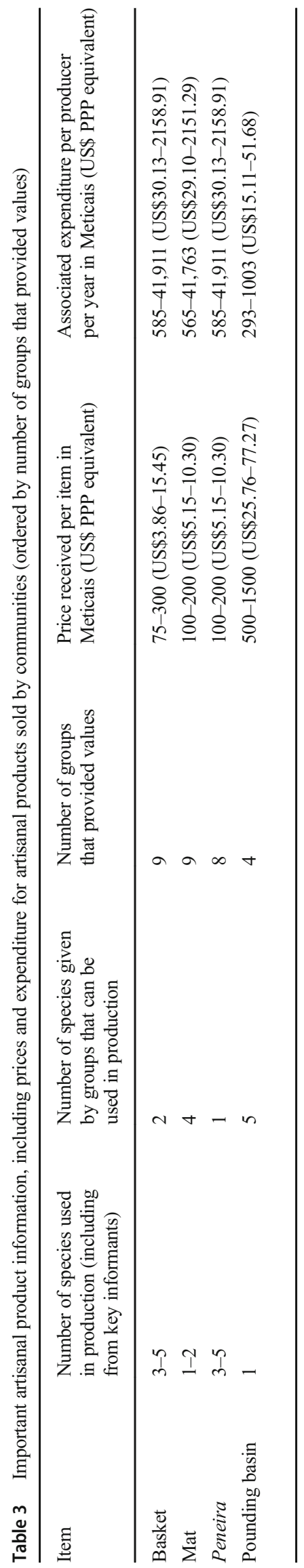

Zomba communities reported that a cup of Strychnos madagascariensis powder sells for between 5 and $35 \mathrm{Mt}$ (US\$0.26 to US\$1.80). To clear a profit, between 12 and 335 cups would need to be sold. A cup with maize flour was weighed at $0.2 \mathrm{~kg}(8.4 \mathrm{~cm}$ diameter $\times 7.5 \mathrm{~cm}$ height $\times 26.3 \mathrm{~cm}$ circumference with a weight of $0.08 \mathrm{~kg}$ ). Assuming weight equivalence, a kilogram of S. madagascariensis powder sells for between 25 and $175 \mathrm{Mt}$ (US\$1.29 to US\$9.01). Therefore, the sale of between $2.3 \mathrm{~kg}$ and $67.0 \mathrm{~kg}$ would cover the associated expenditures.

Zomba - Muranga women's group mentioned that in Sofala province they understand how to process and sell Strychnos madagascariensis powder better than in Zomba, and that they sell a lot in Dombé market. Attendees at all Zomba meetings expressed a desire to learn to produce more powder as a livelihood option.

Other important species were voted for by more than one group (Table 5), and the Mussimua - Munhinga-1 participants mentioned that Vitex spp. fruits are also sold in local markets.

Finally, the Zomba - Muranga men's group stated that Mudjangua (Entada rheedii) is valued because it is consumed in times of scarcity. The fruit is collected, burnt, and submerged in water for 2-3 days before it is ready to be cooked.

\section{Discussion}

Our research provides data on indigenous species resources available in the Chimanimani TFCA that are important to local communities and thus may be suitable targets for use in sustainable development projects (van Andel et al. 2015; Pei et al. 2009; Towns et al. 2013). They are not necessarily the most threatened in southern Africa, although there is evidence of pressure on their habitats (Chagumaira et al. 2016; Gebramlak et al. 2016; MLERD 2015; van Dam et al. 2014). Resource use is dependent on local availability, with a diversity of species used, as is the case elsewhere in Africa where relevant research has already been undertaken (Chagumaira et al. 2016; Khan et al. 2016; Kotze and Traynor 2011; Mojeremane and Lumbile 2016; Mugisha et al. 2007; Ngadze et al. 2017a; Ngadze et al. 2017b; Shackleton 2002; Terer et al. 2012; van Dam et al. 2014). Oxytenanthera absyssinica and Uapaca kirkiana were the only resources with broad use across the communities we investigated.

There is evidence that species' populations in more populated areas that are closer to roads are being depleted. This has led to less diversity of wood species being harvested and less accessibility to those mentioned by participants. It is these areas where conversion of forests to agriculture and overexploitation are key issues and in which communities need more sustainable livelihood options. 


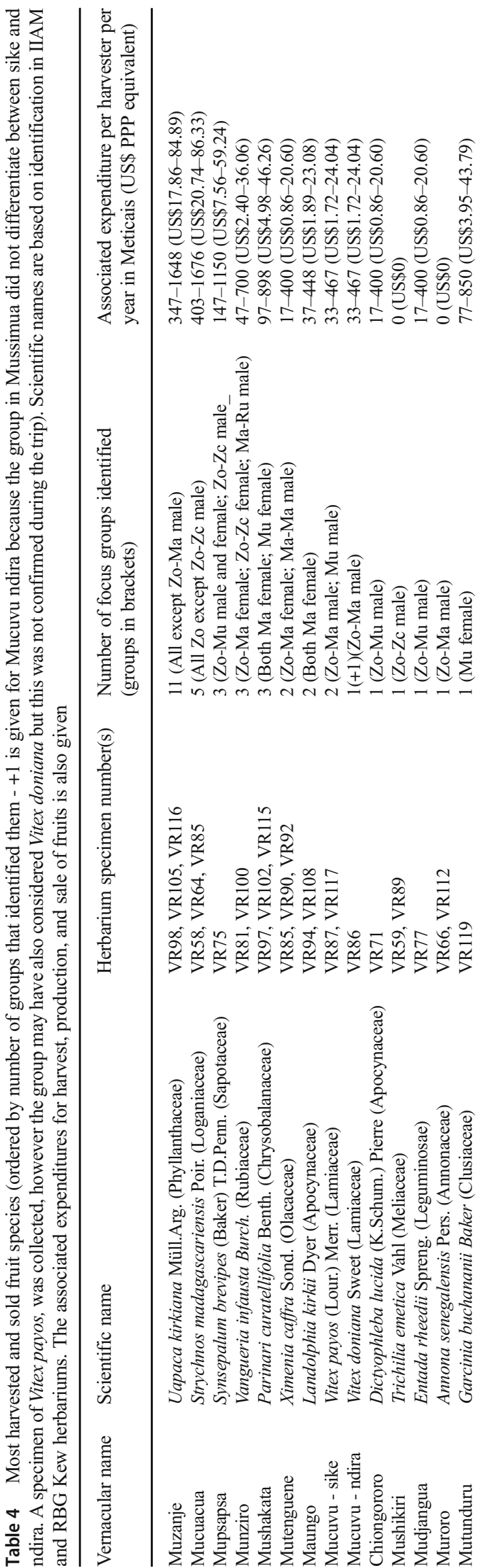

Some tree species, such as Pterocarpus angolensis and Afzelia quanzensis, slow growth rates and dieback phases and low recruitment rates, are most the susceptible (Caro et al. 2005; Chidumayo 1992; Mojeremane and Lumbile 2016). Protection of remaining populations will be important for these species (Laird et al. 2010; Shackleton 2002), with replacement of other known species such as Funtumia africana or Albizia versicolor that could be used in monocyclic silvicultural systems (Kiama and Kiyiapi 2015; Omeja et al. 2004).

Many artisanal products (pounding basins, peneiras and baskets) are important to the maize industry for processing and storage so loss of without these resources could impact the livelihoods of both the artisans and maize producers. These social values may mean communities are more willing to protect them and the wider environments important to them, even in less economically advantageous situations (Virtanen 2005).

Sustainable use of these plants needs to combine local ecological and scientific knowledge to target appropriate environmental strategies. Oxytenanthera abyssinica, for example, has economic importance in agroforestry and may be propagated from seed (Embaye et al. 2003; Gebramlak et al. 2016) so technical and financial support for domestication and management projects could be useful.

The two most frequently high ranked fruits (Uapaca kirkiana and Strychnos madagascariensis) showed voting evenly split between genders. This is probably because the fruits are known, collected, and consumed by everybody across the communities. They represent a nutrition and income source outside of the maize harvest season (March to May) (Hines and Eckman 1993; Khan et al. 2016; Ngadze et al. 2017b). Both have local market value and $U$. kirkiana is protected by traditional rules and practices that benefit their shelf life and palatability, an important consideration to incorporate into sustainable management for the future (Kadzere et al. 2007; Rankoana 2016).

\section{Commercialisation for Conservation of Wild Products}

Virtanen (2005) suggests crafts, medicines, and protein from hunting represent the few local forest products that have ready markets in the TFCA area. Our study has shown fruits also have local markets, similar to those in Zimbabwe (Chagumaira et al. 2016).

Socioeconomic elements for successful NTFP commercialisation are present locally: markets for wild products, market access (particularly in Zomba and Mussimua), local interest, and improved tenure (Gebramlak et al. 2016; Phelps et al. 2013; Walker 2012). Some wild species also have characteristics that would be important to successfully sustainable development, such as expanded NTFP production (fruits 
Table 5 Monthly calendar of community activities: planting and harvest of maize and harvest of the most important wild fruits. Maize planting includes field preparation and planting of the crop. Artisanal species were nearly always mentioned as year-round activities and so are not shown. Values are the number of focus group meetings that reported the month. Light grey $=1$ focus group, grey $=2$ focus groups, dark grey $=3$ or more focus groups

\begin{tabular}{|c|c|c|c|c|c|c|c|c|c|c|c|c|}
\hline Species & Jan & Feb & Mar & Apr & May & Jun & Jul & Aug & Sep & Oct & Nov & Dec \\
\hline Maize harvest & 1 & 2 & 9 & 8 & 6 & 2 & & & 1 & & 1 & 1 \\
\hline Maize planting & & & & 1 & & 1 & 1 & 3 & 3 & 12 & 10 & 2 \\
\hline $\begin{array}{l}\text { Strychnos } \\
\text { madagascariensis }\end{array}$ & & & & & & & & & & 2 & 4 & 3 \\
\hline Uapaca kirkiana & & & & & & & & 1 & 2 & 7 & 9 & 6 \\
\hline $\begin{array}{l}\text { Synsepalum } \\
\text { brevipes }\end{array}$ & & 1 & & & & & & & & 1 & 2 & 1 \\
\hline $\begin{array}{l}\text { Parinari } \\
\text { curatellifolia }\end{array}$ & & & & & & & & 2 & 2 & 1 & 1 & \\
\hline Ximenia caffra & & & 1 & & & & & & & & & 1 \\
\hline $\begin{array}{l}\text { Vangueria } \\
\text { infausta }\end{array}$ & & & 1 & 2 & & 1 & 1 & & & & & \\
\hline Landolphia kirkii & & & & & & & & & & 2 & 2 & 1 \\
\hline Vitex payos & & & & & 2 & 2 & & & & & & \\
\hline Vitex doniana & & 1 & 1 & & & & & & & & & \\
\hline
\end{tabular}

from stands of Uapaca kirkiana and prestigious growth from Oxytenanthera abyssinica, Cyperus spp. and Phragmites mauritianus) and production in years of droughts (Strychnos madagascariensis fruits).

In Manica, over the previous two-year period to this study, retail prices for maize fluctuated between 9.14 and $29.52 \mathrm{Mt} / \mathrm{kg}$ (US $\$ 0.47 / \mathrm{kg}$ to US\$1.52/kg) (FAO 2017). Using maximum Mozambican average yields from 2009 to $1.2 \mathrm{t} / \mathrm{ha}$ (Dias 2013) - the potential income from one hectare is 10,968 to $35,424 \mathrm{Mt}$ (US\$564.98 to US\$1824.76). This is equivalent to $65.3 \mathrm{~kg}$ to $1484 \mathrm{~kg}$ of Strychnos madagascariensis powder (including associated expenditure cover from sale of between $2.3 \mathrm{~kg}$ to $67.0 \mathrm{~kg}), 1097$ to 7085 bunches of Uapaca kirkiana (4388 to 28,339 fruits), or $1157 \mathrm{~kg}$ to $3742 \mathrm{~kg}$ (including associated expenditure cover from sale of between 60 to $200 \mathrm{~kg}$ ) of $U$. kirkiana fruits when sold in $20 \mathrm{~kg}$ containers in town.

In an area of Zimbabwe, Mithöfer and Waibel (2003) showed that each household sold 9200 U. kirkiana fruits in 2000. Even with the highest estimate of associated expenditures of 1320 fruits, this represents income comparable to the sale $7880 \mathrm{~kg}$ of maize for households with small land holdings. This may be part of the reason the $U$. kirkiana stands in Mussimua have not been converted to farmland. Public goods potentially lost in agricultural conversion could retain an actual value that may be much more than maize in an equivalent area (Angelsen 2010; Sunderlin et al. 2005).
Increased incomes run the risk of being pumped into further expansion of profit-making activities with elite capture and overexploitation that can lead to poor outcomes for the community as a whole (Angelsen 2010; Dove 1993; Sunderlin et al. 2005). To avoid these, research is vital to assess sustainable harvest rates, to monitor the ecological impacts of increased use, and to sustain communities' participation in management decisions (Dzerefos et al. 2016). To ensure land rents of natural areas with wild species used for nutrition, medicine, and other artisanal and cultural purposes increase with any increases in agricultural rent, additional value could improve product variety and longevity (Phelps et al. 2013).

Such an approach would allow the Chimanimani TFCA to adhere to the South African Development Community Protocols and plans for sustainable management (Ghiurghi et al. 2010; MLERD 2015; SADC 1999, 2002; SADC Secretariat 2013). This would at the same time contribute to Mozambique's National strategy and action plan for biodiversity meeting the Convention on Biological Diversity Aichi targets and Sustainable Development Goals (CBD 2010; UN General Assembly 2015).

\section{Study Limitations}

We would recommend that future research investigate all community groups in the regulados, and all regulados. With all community groups included, and the addition of household 
surveys, analysis could provide a fuller picture of use and values of species and habitats across the TFCA showing intra- and inter-community variability.

There is also need for in-depth ethnobotanical study to identify valuable medicines, firewood, and further food sources (e.g., root vegetables, leaves, mushrooms). These also support livelihoods and so could offer development opportunities (Angelsen et al. 2014). It is also important for the preservation of traditional ecological knowledge since species-use may vary as climate and land use change impact local biodiversity.

More frequent surveys throughout the year would reduce inaccuracies of participants' recall. Repeating the survey in different seasons would more accurately reflect actual resource use (Bakkegaard et al. 2016).

Further research on how local social relations - power, gender, kinship, or ritual - impact the use of wild products would allow a more detailed accounting of actual resource use (Angelsen et al. 2014; Ghimire et al. 2005; Goebel 2003; Schafer and Bell 2002), which is important in planning development strategies to ensure equitable distribution of benefits throughout the community (Dove 1993).

The botanical properties of the utilized plants themselves need to be fully understood in terms their potential to supplement livelihood income, their use as raw materials for artisanal products (Kiama and Kiyiapi 2015; Kotze and Traynor 2011; Mugisha et al. 2007; Omeja et al. 2004; Terer et al. 2012; van Dam et al. 2014) or their nutritional benefits (Hines and Eckman 1993; Khan et al. 2016; Mithöfer and Waibel 2003; Ngadze et al. 2017a; Ngadze et al. 2017b; Towns et al. 2013; Towns and van Andel 2016).

\section{Conclusions}

Wild indigenous species are important to many communities across Africa and in other areas of the world for the manufacture of artisanal products and as supplementary sources of food for local consumption and markets. Our study identified important species within three 'regulados' in the Chimanimani Trans-Frontier Conservation Area, Mozambique.

Of those highlighted by focus groups and key informants, those used for artisanal crafts, Cyperus sp., Phragmites mauritianus, and Oxytenanthera abyssinica, should be monitored because of their importance to local livelihoods, as well as their economic potential, although competition with mass produced alternatives may prove difficult. Pterocarpus angolensis is the wood species most in need of conservation (except in Mahate regulado), although Funtumia africana and Albizia versicolor are potential alternative species. Uapaca kirkiana and Strychnos madagascariensis seem the most suitable fruit species for development in Mussimua and Zomba respectively.

When considering further livelihood options, it will be important to identify how the communities' value all species and habitats beyond provisioning services. Landscape scale analyses of the changes occurring across habitats would identify the areas most under threat. These would provide important data for policy and management options that have the greatest conservation and community benefits. They would also help assess the effectiveness of development strategies with implications for replication elsewhere.

\section{Further Investigations}

We recommend the following social, ecological, and economic studies to develop alternative sustainable development policies and standards that support conservation objectives within the Chimanimani TFCA:

(1) Investigation of the extent of populations of important valued wild species and measurement of their production levels, including yearly fluctuations, to assess their viability for sustainable use and provide baseline data for monitoring and management.

(2) Comprehensive socioeconomic household surveys to assess variability in valuations, costs, and traditional ecological knowledge associated with wild species and natural areas in order to identify trade-offs between land use options and to understand local management practices and perceived environmental problems.

(3) Analysis of deforestation over the past 20 years using satellite imagery to identify which habitats have been most impacted and are most at risk. Together with social surveys, this would highlight interactions with local people's valuations and perceptions and allow assessment of the success of development strategies.

(4) Comprehensive ecological and restoration studies for important species already being lost (e.g., Pterocarpus angolensis, Afzelia quanzensis, Oxytenanthera abyssinica and Urena lobata), including germination and propagation trials where needed.

Such studies would provide an important database for policy makers and development agencies, both national and nongovernmental, to identify threatened habitats in need of conservation and populations willing to protect and incorporate native species into community livelihood development strategies.

Acknowledgements We thank Bentham-Moxon Trust for funding the expedition (Grant: BMT13-2016. Awarded in 2016); the Darwin Initiative for supporting the initial project which formed the partnerships for this project; 
MICAIA Foundation and Instituto de Investigação Agrária de Moçambique (IIAM) for their support, without whom conversations with the communities would not have been possible. We are also grateful to the study communities for their time and participation, and our guides for directing us to the plants to collect as herbarium specimens. Thanks also to the translators in focus meetings. Thanks to Jossias Zandamela, Iain Darbyshire, and Jo Osborne in the IIAM and Royal Botanic Gardens, Kew, herbariums for help with identifying specimens. Thanks to Camila de Sousa for her help in pulling together the permissions for the trip and for her help in Maputo. Thank you also to Rosalind Bark for manuscript comments and Vaitehi Nageshwaran for help with data and edits.

\section{Compliance with Ethical Standards}

Conflict of Interest The authors declare they have no conflicts of interest.

Open Access This article is licensed under a Creative Commons Attribution 4.0 International License, which permits use, sharing, adaptation, distribution and reproduction in any medium or format, as long as you give appropriate credit to the original author(s) and the source, provide a link to the Creative Commons licence, and indicate if changes were made. The images or other third party material in this article are included in the article's Creative Commons licence, unless indicated otherwise in a credit line to the material. If material is not included in the article's Creative Commons licence and your intended use is not permitted by statutory regulation or exceeds the permitted use, you will need to obtain permission directly from the copyright holder. To view a copy of this licence, visit http://creativecommons.org/licenses/by/4.0/.

\section{References}

Abrahams, P., Bateman, M., Beale, T., Clottey, V., Cock, M., Colmenarez, Y., Corniani, N., Day, R., Early, R., Godwin, J., Gomez, J., Moreno, P. G., Murphy, S. T., Oppong-mensah, B., Phiri, N., Pratt, C., Richards, G., Silvestri, S., and Witt, A. (2017). Fall armyworm: Impacts and implications for Africa. Evidence Note 2(September): 144 pp.

Albuquerque, U. P., and Hanazaki, N. (2009). Five problems in current ethnobotanical research - and some suggestions for strengthening them. Human Ecology 37(5): 653-661. https://doi.org/10.1007/ s10745-009-9259-9.

Angelsen, A. (2010). Policies for reduced deforestation and their impact on agricultural production. PNAS 107(46): 19639-19644. https:// doi.org/10.1073/pnas.0912014107.

Angelsen, A., Jagger, P., Babigumira, R., Belcher, B., Hogarth, N. J., Bauch, S., Börner, J., Smith-Hall, and Wunder, S. (2014). Environmental income and rural livelihoods: A global-comparative analysis. World Development 64(S1): S12-S28. https://doi.org/10.1016/j.worlddev. 2014.03.006.

Angiosperm Phylogeny Group (2009). An update of the angiosperm phylogeny group classification for the orders and families of flowering plants: APG III. Bot. J. Linn. Soc. 161: 105-121.

Bakkegaard, R. K., Agrawal, A., Animon, I., Hogarth, N., Miller, D., Persha, L., Rametsteiner, E., Wunder, S., and Zezza, A. (2016). "National socioeconomic surveys in forestry: guidance and survey modules for measuring the multiple roles of forests in household welfare and livelihoods." FAO Forestry Paper No. 179. Food and Agriculture Organization of the United Nations, Center for International Forestry Research, International Forestry Resources and Institutions Research Network, and World Bank. Retrieved from http://www.fao.org/3/a-i6206e.pdf.

Caro, T. M., Sungula, M., Schwartz, M. W., and Bella, E. M. (2005). Recruitment of Pterocarpus angolensis in the wild. Forest Ecology and Management 219(2-3): 169-175. https://doi.org/10.1016/j. foreco.2005.07.004.

CBD. (2010). Strategic Plan for Biodiversity 2011-2020. Convention on Biological Diversity, 10th Conference of Parties.

Chagumaira, C., Rurinda, J., Nezomba, H., Mtambanengwe, F., and Mapfumo, P. (2016). Use patterns of natural resources supporting livelihoods of smallholder communities and implications for climate change adaptation in Zimbabwe. Environment, Development and Sustainability 18(1): 237-255. https://doi.org/10.1007/s10668-015-9637-y.

Chidumayo, E. N. (1992). Effects of shoot mortality on the Early development of Afzelia quanzensis seedlings. Journal of Applied Ecology 29(1): 14-20. https://doi.org/10.2307/2404342.

Dias, P. (2013). Analysis of incentives and disincentives for maize in Mozambique, Food and Agriculture Organisation, Rome.

Dove, M. R. (1993). A revisionist view of tropical deforestation and development. Environmental Conservation 20(1): 17-24.

Dzerefos, C. M., Witkowski, E. T. F., and Kremer-köhne, S. (2016). Aiming for the biodiversity target with the social welfare arrow: medicinal and other useful plants from a Critically Endangered grassland ecosystem in Limpopo Province, South Africa. International Journal of Sustainable Development \& World Ecology 24(1): 52-64. https://doi.org/10.1080/ 13504509.2016.1174963.

Embaye, K., Christersson, L., Ledin, S., and Weih, M. (2003). Bamboo as bioresource in Ethiopia: Management strategy to improve seedling performance (Oxytenanthera abyssinica). Bioresource Technology 88(1): 33-39. https://doi.org/10.1016/S0960-8524(02)00265-1.

FAO. (2017). GIEWS FPMA - Global Information and Early Warning System Food Price Monitoring and Analysis Tool: Mozambique. Available from: http://www.fao.org/giews/food-prices/tool/ public/\#/dataset/domestic [Accessed on 10/10/2017].

Gebramlak, G. D., Abadi, N., and Hizikias, E. B. (2016). Socioeconomic contribution of Oxytenanthera abyssinica (a.Rich) Munro and determinants of growing in homestead agroforestry system in northern Ethiopia. Ethnobotany Research and Applications 14(14): 479-490. https://doi.org/10.17348/era.14.0.479-490.

Ghimire, S. S. K., McKey, D., and Aumeeruddy-Thomas, Y. (2005). Heterogeneity in ethnoecological knowledge and management of medicinal plants in the Himalayas of Nepal: Implications for conservation. Ecology and Society 9(3): 6 Retrieved from http://www. ecologyandsociety.org/vol9/iss3/art6/main.html.

Ghiurghi, A., Dondeyne, S., and Bannerman, J. H. (2010). Chimanimani Conservation Area Management Plan. Report prepared by AgriConsulting for the ministry of tourism, Maputo, Mozambique.

Goebel, A. (2003). Chapter 6: Gender and Entitlements in the Zimbabwean Woodlands: A Case Study of Resettlement. In Howard, P. L. (ed.), Women and Plants. Gender Relations in Biodiversity Management and Conservation, Zed Books, London, p. 273.

Hines, D. A., and Eckman, K. (1993). Indigenous multipurpose trees of Tanzania: Uses and economic benefits for people (93 No. 9), Food and agriculture organisation, Rome.

Kadzere, I., Watkins, C. B., Merwin, I. A., Akinnifesi, F. K., and Saka, J. D. K. (2007). Harvest date affects colour and soluble solids concentrations (SSC) of Uapaca kirkiana (Muell. Arg.) fruits from natural woodlands. Agroforestry Systems 69(2): 167-173. https://doi.org/ 10.1007/s10457-006-9028-3.

Khan, M. A., Inguane, S., and Svanberg, U. (2016). Contribution of native fruits to alleviation of poverty and malnutrition in rural areas in Mozambique. In Gracie, A., Taguchi, M., Rogers, G., and Appiah, F. (eds.), XXIX International Horticultural Congress on Horticulture: Sustaining Lives, Livelihoods and Landscapes (IHC2014): International Symposium on Horticulture in Developing Countries and World Food Production, Acta Horticulturae, Brisbane, pp. 73-78. https://doi.org/10.17660/ActaHortic.2016.1128.10.

Kiama, D., and Kiyiapi, J. (2015). Shade tolerance and regeneration of some tree species of a tropical rain Forest in Western Kenya. Plant Ecology 156(2): 183-191. 
Kotze, D. C. K., and Traynor, C. H. (2011). Wetland plant species used for craft production in Kwazulu-Natal, South Africa: Ethnobotanical knowledge and environmental sustainability. Economic Botany 65(3): 271-282.

Laird, S. A., McLain, R. J., and Wynberg, R. P. (2010). Wild product governance: Finding policies that works for non-Timber Forest products, Earthscan, London.

Ministry of Land, Environment and Rural Development (MLERD). (2015). National strategy and action plan of biological diversity of Mozambique. MITADER, Maputo.

Mithöfer, D., and Waibel, H. (2003). Income and labour productivity of collection and use of indigenous fruit tree products in Zimbabwe. Agroforestry Systems 59(3): 295-305. https://doi.org/10.1023/B: AGFO.0000005230.09714.b4.

Mojeremane, W., and Lumbile, U. A. (2016). A review of Pterocarpus angolensis DC (Mukwa) an important and threatened Timber species of the Miombo woodlands. Research Journal of Forestry 21(1): 314-317. https://doi.org/10.3923/rjf.2016.Review.

Mugisha, P., Kansiime, F., Mucunguzi, P., and Kateyo, E. (2007). Wetland vegetation and nutrient retention in Nakivubo and Kirinya wetlands in the Lake Victoria basin of Uganda. Physics and Chemistry of the Earth 32(15-18): 1359-1365. https://doi.org/10.1016/j.pce.2007.07.040.

Ngadze, R. T., Linnemann, A. R., Nyanga, L. K., Fogliano, V., and Verkerk, R. (2017a). Local processing and nutritional composition of indigenous fruits: The case of monkey orange (Strychnos spp.) from southern Africa. Food Reviews International 33(2): 123-142. https://doi.org/10.1080/87559129.2016.1149862.

Ngadze, R. T., Verkerk, R., Nyanga, L. K., Fogliano, V., and Linnemann, A. R. (2017b). Improvement of traditional processing of local monkey orange (Strychnos spp.) fruits to enhance nutrition security in Zimbabwe. Food Security 9(3): 621-633. https://doi.org/10.1007/ s12571-017-0679-x.

Omeja, P., Obua, J., and Cunningham, A. B. (2004). Regeneration, density and size class distribution of tree species used for drum making in Central Uganda. African Journal of Ecology 42(2): 129-136. https://doi.org/10.1111/j.1365-2028.2004.00509.x.

Peh, K. S. H., Balmford, A., Bradbury, R. B., Brown, C., Butchart, S. H. M., Hughes, F. M. R., Stattersfield, A., Thomas, D. H. L., Walpole, M., Bayliss, J., Gowing, D., Jones, J. P. G., Lewis, S. L., Mulligan, M., Pandeya, B., Stratford, C., Thompson, J. R., Turner, K., Vira, B., Willcock, S., and Birch, J. C. (2013). TESSA: A toolkit for rapid assessment of ecosystem services at sites of biodiversity conservation importance. Ecosystem Services 5: 51-57. https://doi.org/10. 1016/j.ecoser.2013.06.003

Pei, S., Zhang, G., and Huai, H. (2009). Forest ecology and management application of traditional knowledge in forest management: Ethnobotanical indicators of sustainable forest use. Forest Ecology and Management 257(2009): 2017-2021. https://doi.org/10.1016/j. foreco.2009.01.003.

Phelps, J., Carrasco, L. R., Webb, E. L., Koh, L. P., and Pascual, U. (2013). Agricultural intensification escalates future conservation costs. Proceedings of the National Academy of Sciences 110(19): 7601-7606. https://doi.org/10.1073/pnas.1220070110.

Rankoana, S. A. (2016). Sustainable Use and Management of Indigenous Plant Resources: A Case of Mantheding Community in Limpopo Province, South Africa. Sustainability 8(3): 1-13. https://doi.org/10. $3390 /$ su 8030221.

SADC Secretariat. (2013). Southern African development community SADC Programme for Transfrontier conservation areas. SADC Secretariat, Gabaorone.

SADC. (1999). Protocol on wildlife conservation and law enforcement. SADC. (2002). Protocol on forestry.

Schafer, J., and Bell, R. (2002). The state and community-based natural resource management: The case of the Moribane. Journal of Southern African Studies 28(2): 401-420. https://doi.org/10.1080/ 03057070220140775.
Shackleton, C. M. (2002). Growth patterns of Pterocarpus angolensis in savannas of the south African lowveld. Forest Ecology and Management 166(1-3): 85-97. https://doi.org/10.1016/S0378-1127(01)00676-4.

Sunderlin, W. D., Belcher, B., and Wunder, S. (2005). Livelihoods, forests and conservation in developing countries: An overview. World Development 33(9): 1383-1402. https://doi.org/10.1016/j.worlddev. 2004.10.004.

Terer, T., Muasya, A. M., Dahdouh-Guebas, F., Ndiritu, G. G., and Triest, L. (2012). Integrating local ecological knowledge and management practices of an isolated semi-arid papyrus swamp (Loboi, Kenya) into a wider conservation framework. Journal of Environmental Management 93(1): 71-84. https://doi.org/10.1016/j.jenvman. 2011.08.005.

The World Bank. (2018). World Bank Open Data. Available online: https://data.worldbank.org/indicator/ (Access on 24/10/2018)

Timberlake, J., Darbyshire, I., Wursten, B., Hadj-hammou, J., Mapaura, A., Matimele, H., and Banze, A. (2016a). Chimanimani Mountains: Botany and conservation, RBG Kew, UK (unpublished report. Available online from: https://www.kew.org/sites/default/files/ Chimanimani\%20CEPF\%20report\%202016_FINAL.pdf).

Timberlake, J., Darbyshire, I., Cheek, M., Banze, A., Fijamo, V., Massunde, J., Chipanga, H., and Muassinar, D. (2016b). Plant Conservation in Communities on the Chimanimani footslopes, Mozambique, RBG Kew, UK (unpublished report. Available online from: https://www.kew.org/sites/default/files/Chimanimani\% 20Darwin\%20report\%2C\%20FINAL.pdf).

Towns, A. M., Potter, D., and Idrissa, S. (2013). Cultivated, caught, and collected: Defining culturally appropriate foods in Talle. Development in Practice 23(2): 169-183. https://doi.org/10.1080/ 09614524.2013.771985.

Towns, A. M., and van Andel, T. (2016). Wild plants, pregnancy, and the food-medicine continuum in the southern regions of Ghana and Benin. Journal of Ethnopharmacology 179: 375-382. https://doi. org/10.1016/j.jep.2016.01.005.

United Nations General Assembly. (2015). "Transforming our world: the 2030 Agenda for Sustainable Development." General Assembly 70 session (A/RES/70/1). https://doi.org/10.1007/s13398-014-0173-7. 2.

van Andel, T. R., Croft, S., Van Loon, E. E., Quiroz, D., Towns, A. M., and Raes, N. (2015). Prioritizing west African medicinal plants for conservation and sustainable extraction studies based on market surveys and species distribution models. Biological Conservation 181: 173-181. https://doi.org/10.1016/j.biocon.2014.11.015.

van Dam, A. A., Kipkemboi, J., Mazvimavi, D., and Irvine, K. (2014). A synthesis of past, current and future research for protection and management of papyrus (Cyperus papyrus L.) wetlands in Africa. Wetlands Ecology and Management 22(2): 99-114. https://doi.org/ 10.1007/s11273-013-9335-1.

Virtanen, P. (2005). Community-based natural resource management in Mozambique: A critical review of the concept's applicability at local level. Sustainable Development 13(1): 1-12. https://doi.org/10. $1002 /$ sd. 240

Walker, M. M. (2012). A spatio-temporal mosaic of land use and access in Central Mozambique. Journal of Southern African Studies 38(3): 699-715. https://doi.org/10.1080/03057070.2012.711080.

Weckerle, C. S., de Boer, H. J., Puri, R. K., van Andel, T., Bussmann, R. W., and Leonti, M. (2018). Recommended standards for conducting and reporting ethnopharmaco field studies. Journal of Ethnopharmacology 210: 125-132.

Wursten, B., Timberlake, J., and Darbyshire, I. (2017). The Chimanimani mountains: An updated checklist. Kirkia 19(1): 70-100.

Publisher's Note Springer Nature remains neutral with regard to jurisdictional claims in published maps and institutional affiliations. 